\title{
Comparison of normal saline and balanced crystalloid intravenous therapy during neurosurgery
}

\author{
Natasa Kovac*, Inga Mladic Batinica\#, Dijana Kukin*, \\ Tamara Murselovic*, Dinko Tonkovic* \\ * UHC ZAGREB, \# UHC Sestre milosrdnice, Croatia
}

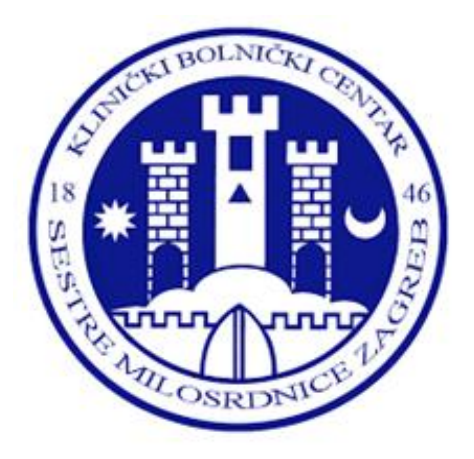

BACKGROUNDS: Normal saline or $0.9 \% \mathrm{NaCl}$ solution is the most commonly used intravenous fluid worldwide and its composition are $154 \mathrm{mmol} \mathrm{Na}+$ and $154 \mathrm{mmol} \mathrm{Cl}$ - per litter with osmolarity of $308 \mathrm{mOsmol} / \mathrm{L}$. That composition is not "normal" because plasma contains sodium in range between $137-146 \mathrm{mmol} / \mathrm{L}$, and chloride in range between 98-106 $\mathrm{mmol} / \mathrm{L}$, with plasma osmolality of $280-295 \mathrm{mOsmol} / \mathrm{kg}$. Recently published data suggested detrimental effects of chloride rich fluids on renal blood flow and glomerular filtration rate, urine output and acute kidney injury. One alternative to saline solution is a buffered, balanced, crystalloid solution with an electrolyte composition similar to plasma and osmolarity between 286-295 $\mathrm{mOsmol} / \mathrm{L}$. Someone could indicate that such balanced solutions are not suitable for neurosurgica patients because of a possible impact on the brain oedema development.

RESULTS: There were no differences in patient demographic data, preoperative electrolyte values and kidney function parameters. The amount of given fluids were similar, $2772 \pm 378.4$ $\mathrm{ml}$ of balanced fluids and $2500 \pm 547.7 \mathrm{ml}$ of normal saline, $p=0.27$. There were no differences between groups of patients in acid base balance, arterial lactate, potassium and sodium. The significant differences in chloride plasma concentration were found in normal saline group of patients during operation, and between groups (Table 1). Chloride plasma level in normal saline group was $103.3 \pm 0.8 \mathrm{mmol} / \mathrm{L}$ preoperative and $113.2 \pm 4.6 \mathrm{mmol} /$ postoperative, $p<0.05$. In Plasma-Lyte 148 group there was no change in chloride concentration during operation. Diuresis was significantly different between groups, balanced solution group had $1677.7 \pm 1103.4 \mathrm{ml}$ diuresis vs. $500 \pm 178.1 \mathrm{ml}$ in normal saline group, $p<0.05$. Plasma osmolality was similar, $286.3 \pm 6.7$ $\mathrm{mOsmol} / \mathrm{L}$ in balanced solution group and $285.8 \pm 6.6$ in normal saline group, $p=0.9$.

There were no adverse events in both groups.

CONCLUSIONS: The balanced crystalloid intravenous therapy during neurosurgery provides better chloride level balance as well as diuresis. There were no changes in plasma osmolality and sodium concentration; therefore the balanced crystalloid fluids (Plasma-Lyte 148) are safe to use in intraoperative fluid maintenance during neurosurgery.

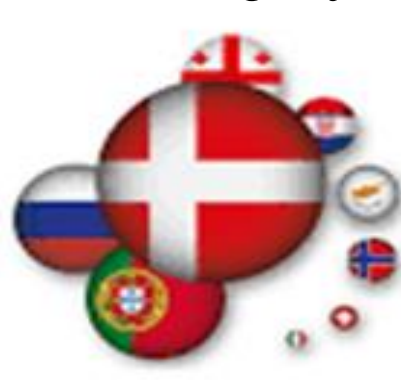

METHODS: We analyzed thirty patients who underwent neurosurgical procedure because of brain tumor, meningeoma and vascular malformation. Patients were divided into two groups according to the type of intraoperative intravenous fluid therapy, normal saline vs. balanced crystalloid solution (Plasma-Lyte 148), which were administered by attending anaesthesiologist. First acid base and electrolyte parameters were obtained after anesthesia induction. Concurrently ventilation and hemodymanic parameters and diuresis were recorded. After each $500 \mathrm{ml}$ of intravenous fluid the acid base and electrolyte status were repeated as well as ventilation and hemodynamic parameters and diuresis. Upon patient arrival in intensive care unit the same parameters were obtained, and urea, creatinine and plasma osmolality, too.

Table 1. Intraoperative and postoperative variables

\begin{tabular}{|c|c|c|c|}
\hline & Normal saline group & $\begin{array}{r}\text { Plasma-Lyte } 148 \\
\text { group }\end{array}$ & $\mathrm{p}$ value \\
\hline $\begin{array}{r}\text { Intraoperative crystalloid } \\
\text { fluid }(\mathrm{ml})\end{array}$ & $2500.0 \pm 547.7$ & $2772.0 \pm 378.4$ & 0.27 \\
\hline $\begin{array}{r}\text { Intraoperative diuresis } \\
(\mathrm{ml})\end{array}$ & $500.0 \pm 178.0$ & $1677.7 \pm 1103.4$ & $<0.05$ \\
\hline $\begin{array}{r}\text { Plasma osmolality } \\
(\mathrm{mOsmol} / \mathrm{L})\end{array}$ & $285.8 \pm 6.6$ & $286.3 \pm 6.7$ & 0.90 \\
\hline $\begin{array}{r}\text { SAPS II (at discharge } \\
\text { from ICU) }\end{array}$ & $18.0 \pm 5.7$ & $20.2 \pm 5.4$ & 0.45 \\
\hline $\begin{array}{r}\text { Postoperative urea } \\
(\mathrm{mmol} / \mathrm{L})\end{array}$ & $6.4 \pm 3.2$ & $5.0 \pm 2.0$ & 0.34 \\
\hline $\begin{array}{l}\text { Postoperative creatinine } \\
\qquad(\mu \mathrm{mol} / \mathrm{L})\end{array}$ & $76.2 \pm 15.3$ & $67.5 \pm 14.8$ & 0.29 \\
\hline $\begin{array}{r}\text { Plasma chloride after } 200 \\
\mathrm{ml} \text { of crystalloid fluid } \\
(\mathrm{mmol} / \mathrm{L})\end{array}$ & $109.3 \pm 3.0$ & $105.3 \pm 3.0$ & $<0.05$ \\
\hline $\begin{array}{r}\text { Plâssma chloride after } \\
1000 \mathrm{ml} \text { of crystalloid } \\
\text { fluid (mmol/L) }\end{array}$ & $111.0 \pm 3.6$ & $106.1 \pm 3.0$ & $<0.05$ \\
\hline $\begin{array}{r}\text { Plasma chloride after } \\
1500 \mathrm{ml} \text { of crystalloid } \\
\text { fluid (mmol/L) }\end{array}$ & $112.2 \pm 5.7$ & $106.5 \pm 2.5$ & $<0.05$ \\
\hline $\begin{array}{r}\text { Plasma chloride after } \\
2000 \mathrm{ml} \text { of crystalloid } \\
\text { fluid }(\mathrm{mmol} / \mathrm{L})\end{array}$ & $113.2 \pm 4.6$ & $104.3 \pm 1.4$ & $<0.05$ \\
\hline
\end{tabular}

